\title{
English for Academic Purposes: English for general skills Writing Course
}

\author{
Samah Thabet Sayed \\ The English Department-Faculty of Arts- Cairo University- Egypt \\ samah. thabet@gmail.com
}

\begin{abstract}
This paper comprises a full plan of an in-sessional EAP writing course that was conducted on a group of monolingual undergraduates in KSA. It aimed to upgrade the quality of their writing and enhance their analytical and critical thinking skills to meet their immediate, specific vocational and professional needs and ultimately develop their overall writing proficiency. The eclectic teaching approach is adopted to synthesize process, product and genre approaches to writing; the tasks are varied, graded in level and cyclical in nature to meet learners' divergent needs and cover the different stages of the writing process. The study, then, offers multiple tools of evaluation and assessment to clearly highlight the course's benefits as well as constraints and suggests soltuions to design better future courses.
\end{abstract}

Keywords: eap, writing, critical thinking, vocational needs, argumentative discourse, skillsbased, writing proficienc

\section{Introduction}

EAP (English for Academic Purposes) refers to a specialized English-language teaching 'of research and instruction that focuses on the specific communicative needs and practices of particular groups in academic contexts' (Hyland, 2006: 1).

As stated by Jordan (2009), EAP has come to prominence as a subfield of English for specific purposes in the early 1980s. Its rise has been in response to the growing need for intercultural awareness and of English as a lingua franca (ELF). Meanwhile, the increase in students undertaking tertiary studies in English-speaking countries led to a steady demand for courses tailored to meet immediate, specific vocational and professional needs (Hyland, 2006).

The researcher has chosen EAP as her specialism due to her awareness of the crucial role of academic skills that are currently prioritized in most universities. The researcher is keen on furthering expertise in that particular respect to cater for the needs of learners and simultaneously enhance her job prospects.

The study implements different tools of NA (2.3) to chart learners' priorities and set the goals and objectives (3.1/3.2). An eclectic teaching approach is adopted to optimize the learning process and develop learners' macro writing skill as well as micro skills like brainstorming, outlining and proofreading. Variant assessment and evaluation tools (Part 4) are utilized to point out the course's limitations and provide suggestions for future courses.

\subsection{EAP different contexts}

EAP greatly differs from other General English (GE) courses (Rogers, 2010):

- EAP courses are goal-oriented: Needs analysis findings impact teaching methods and materials selection. The stakes are higher as the students' success will determine their eligibility to proceed with future study. Unlike GE learners, EAP learners tend to be adults over 18 who 
are generally more instrumentally motivated; they need to improve their English to attain academic success and communicate effectively.

- Moreover, more reliance is on productive skills in EAP classrooms. Activities that depend on register, genres and discourse are prioritized over grammar and vocabulary.

- Tutors also face numerous challenges in EAP classes: they have a greater sense of purpose than GE teachers because their courses are tailored to develop the competencies needed for a special group of learners. They may need to devise their own materials, sometimes collaborate with other subjects' teachers or research into academic genres unrelated to their major. They, hence, play multiple roles as course designers ,materials providers, researchers, collaborators and assessors.

Typically, EAP students fall into two main categories (Hyland \& Hamp- Lyons, 2002):

- Pre-tertiary undergraduates or postgraduates, who join EAP 'pre-sessional' courses, either at home country or overseas, belong to the first category. They want to improve their academic communication skills in English to join an English-medium university.

- Learners who join "in-sessional" classes, while studying their mainstream subjects, form the second category. They need assistance to cope with their specific disciplines.

Increasingly, international students have been taking EAP courses as part of their degree. These courses tend to be sub-divided as 'either common core or subject specific' (Hyland, 2006:10): ESAP (English for a specific academic purpose, designed to prepare students for a particular discipline such as medicine, engineering, etc.), or EGAP (English for general skills related to a wider range of disciplines such as: academic writing, delivering presentations, etc.).

\subsection{Review of Literature:}

A number of key issues were considered in prior studies to devise an EAP course:

\subsubsection{Language focus}

EAP courses are often described as skills-based, whereas language should be 'subjectspecific' and 'dealt with somewhat eclectically (rather than systematically)' (Turner, 2004: 96). Still, researchers like Evans and Morrison (2011) suggested that students could be offered English courses that sensitize them to 'the salient rhetorical and linguistic features of key disciplinary genres '(Evans \& Morrison, 2011:389). Simultaneously, they should be generally encouraged to develop a better command of the language. In my experience, learners may have many language problems related to lexico-grammatical accuracy as well as conformity with academic conventions of register, coherence, and the like. The chosen areas for language focus in EAP courses should, accordingly, be based on content- based activities that develop learners' overall language competencies, within the main academic framework.

\subsubsection{Socio-cultural background.}

EAP learners may be homogenous in age, but heterogeneous in culture or disciplines. Scholars like Hyland (2006) and Thorp (1991) argue that acculturation into a new social and institutional culture is tightly related to academic performance. Therefore, EAP instructors need to become aware of their learners divergent socio-cultural norms (Spack, 1988). Learners may bring varying cultural expectations and attitudes towards the new academic milieu they are exposed to. Their families, prior educational context or first language literacy skills might influence them. In my academic writing classes, for example, some learners tend to plagiarize due to their lack of knowledge of referencing conventions and copyrights. Therefore, cultural sensitivity should impact EAP tutors' choice of appropriate texts, activities and discussions in class. In other words, they should diligently try to tolerate leaners' social and academic 
variations and gradually attempt to raise their awareness of themselves as 'cultural beings' (Thorp, 1991:109), able to operate effectively in different academic contexts.

\subsubsection{Question of specificity}

Designing EAP courses and materials forms a real challenge for EAP practitioners. Many favor the EGAP approach as general skills and strategies can be easily transferred to specifc disciplines. ESAP supporters, on the other hand, argue for 'targeting specific contexts' (DudleyEvans \& St John, 1998: 41).

As most university courses become more interdisciplinary nowadays (Jordan, 2009), course developers opt for a study-skills approach (Jordan, 2009; Hyland, 2006) that incorporates core academic, discipline-free practices learners' need to read, write, speak or listen for study purposes. Such generic skills - note taking, summarizing, paraphrasing, scanning, skimming, referencing, etc.- can ultimately bridge the gap between meeting learners' divergent needs and enhancing their overall communicative competence. Meanwhile, discipline specificity can be usefully exploited throughout class discussions and activities to expand learners' knowledge of other disciplines.

\subsubsection{Critical thinking}

Fostering learners' critical thinking is a crucial issue in EAP classrooms. Numerous cognitive strategies (De Chazal, 2013), like inference of meaning from context, guessing, problem solving, etc., help to optimize learners' motivation, and enhance their sense of autonomy to apply them to new contexts related to their specialized disciplines. EAP course designers should, therefore, adopt a student-centered approach (Jordan, 2009) by choosing stimulating, interactive tasks that acknowledge students' multiple intelligences (Cox \& Hill 2011; Guse, 2011) and empower their analytic abilities.

\subsubsection{Time constraints}

EAP learners often grapple with time. Their classrooms are based on 'protracted tasks' that are 'inherently long and dense' (Guse, 2011: 4) -i.e. drafting a discursive essay or delivering a presentation- and cover a series of lessons. Integrating micro-skills like collaborative projects, group discussions and peer reviewing provides 'a new type of literacy' (Hyland, 2002:9) to surmount the obstacle of time in EAP classrooms. Additionally, encouraging learners' self-study in conjunction with reliance on self-access materials can maximize the time needed for further practice and thus enhance both their input and output.

\subsection{Learners' profile}

The course is an in-sessional academic writing course that covers the duration of 24 hours, 2 hours per week. There are 15, mono-lingual female undergraduates, aged 18-20, in this group: 12 Saudis and 3 Jordanians. They can be classified as pre-intermediate learners with a reasonable knowledge of the language and the main principles of academic writing. Their major is Literature, except for the three Jordanians; the course is elective in their IT department. 


\subsection{Needs Analysis: an Overview}

Needs Analysis_is the core element of EAP course design(Hyland 2006; Richards 2001; Graves 2000 ). It 'refers to the techniques for collecting and assessing information ' (Hyland, 2006:73) relevant to create a profile of the language needs, interests and expectations of learners, and establish ' the how and what of a course' (ibid.). Other elements like the learning context and institutional constraints should be considered as well (Richards, 2001).

\subsection{Needs Analysis Tools}

Multiple tools were chosen to cover most of the relevant factors impacting the target course and validate the findings (Long, 2005):

\subsection{1 learning style test}

Wingate's Multiple Intelligence test(1996) was conducted to identify learners' pedagogical preferences (A 3.1.1). It was based on Dr. Howard Gardner's theory (1983) that claimed that different intelligences operate simultaneously, which enables diverse learners to function and progress in class. Learners were to check a range of items in the questionnaire to identify the dominant type of intelligence: linguistic, spatial, kinesthetic, interpersonal, intrapersonal, etc. The teacher then can plan activities that address the learner's intelligence type for a more effective input.

\section{$\underline{\text { 2.3.2 Structured interview }}$}

My starting point has been a structured interview of the academic writing coordinator . I prepared a set of questions (A 3.2) about the parameters for setting course objectives and selecting textbooks. I also questioned her perception of the competencies learners need to acquire in the course. This type of Target situation analysis (TSA) provides mainly objective data (Nunan 1996; Mackay\& Mountford 1978)) about the stakeholders ' vision of learners' language proficiency and the general learning milieu they function in.

\subsubsection{Questionnaire}

I chose to administer a questionnaire as among the most widely used procedures in NA (Mackay \& Mountford 1978; Long 2005). Because it can be completed anonymously in class, learners feel treated as 'individuals' (Graves, 2000), responsible for their learning, and become willing to give truthful answers. My questionnaire (A3.3) aims to provide a Present situation analysis (PSA) of learners as combines both subjective and objective data about their current proficiencies, ambitions and preferred teaching methodology ( Hyland , 2006).

\section{$\underline{\text { 2.3.4 Informal chats }}$}

I had some informal chats with writing teachers about common problems and suggestions for improvement. The lack of pre-determined questions was more relaxing for them to express their ideas freely, while enjoying 'the option of anonymity' (Long, 2005:47). I also held informal group consultations with the students, following the questionnaire, to identify their affective needs and envision their expectations for the target course. 


\subsection{Findings}

- $90 \%$ of learners belong to the 'spatial' type of intelligence and prefer information to be presented in visual, written forms. They are also interpersonal and enjoy group work. (A 3.1.2)

- The interview with the writing co-ordinator (A 2.1.1/A 3.2) emphasized the need for aacademic writing as a compulsory course. He confirmed that the chosen textbook is appropriate to learners' level. In his opinion, they should focus on developing skills like coherence and cohesion to produce a reasonable piece of writing. They are mostly motivated intrinsically to obtain the required IELTS score to be eligible to study abroad

- NAQ data (A2.1.2) indicated that:

- Most students are also hoping to undertake further study abroad. They, thus, have a strong instrumental motivation (Nunan 1996; Williams 1999) that shapes their keenness to enhance their academic writing proficiency.

- Writing forms a challenge to most learners: $60 \%$ of the group believed it to be difficult, while $40 \%$ considered it quite easy. $85 \%$ of learners expressed genuine interest in developing their writing skills to actualize their academic future goals.

- On assessing their writing difficulties, $90 \%$ ranked supporting ideas as the main difficulty they face. $80 \%$ ranked cohesion, spelling and accurate grammar in the top three, while $20 \%$ prioritized punctuation and appropriate word choice.

- Informal chats (A 2.1.3) proved the following: writing instructors believe that most students lack motivation in writing classes due to time-consuming language tasks and dull materials. Similarly, learners hope for less amount of grammar exercises as hectic and do not realistically mirror true writing proficiency and expect more attention from the teachers in terms of providing feedback.

\subsection{Diagnostic test}

Diagnostic tests aim to 'diagnose aspects of a language that a student needs to develop or that a course needs to include' (Brown, 2010:10). They provide information on areas of difficulty (Bynom, 2001) and pinpoint learners' strengths and weaknesses (Hughes, 2003). I conducted one diagnostic, integrative test (A 4.1) in order to build up an analytic profile of the learners' overall command of writing skills. I chose the second writing task from the academic IELTS exam for a number of reasons: Firstly, the majority of learners aim to go through the academic module to study abroad. Secondly, the writing coordinator confirmed the same goal for learners. Thus, the task reconciles students' needs with institutional goals. It is also a sample of real tasks; namely, writing argumentative essays, students will soon encounter in the course and at the final exam - a situation that guarantees high face validity (Hughes, 2003). Thirdly, the task was marked using the IELTS analytic marking scales (A 2.2) that are usually characterized by both validity and reliability.

\subsubsection{Results}

In keeping with NAQ findings, DT collected data (A 2.2.1/ A2.2.2) demonstrated the following strengths and weaknesses: 


\begin{tabular}{|ll|}
\hline Strengths \\
\hline$[1]$ & Planning before writing. \\
{$[2]$} & Logical organization of content. \\
{$[3]$} & Proper paragraphing. \\
{$[4]$} & General awareness of the academic register. \\
\hline Problems identified \\
\hline [1] & Poor development of ideas to express an opinion or validate a cause. \\
{$[2]$} & Limited vocabulary. \\
{$[3]$} & A lack of cohesion, because of misused or sometimes overused cohesive devices. \\
{$[4]$} & Frequent Structural and grammatical inaccuracies; e.g. recurrence of fragments and run-on \\
& lines. \\
{$[5]$} & Poor editing/revising skills \\
\end{tabular}

\subsection{Priorities}

[1] Focusing on ways of supporting ideas- examples, summarizing, paraphrasing, quotations, etc.and expressing opinions analytically.

[2] Enriching students' academic lexical repertoire.

[3] Understanding and using cohesive devices accurately and appropriately.

[4] Developing accurate sentence construction and lexical as well as grammatical cohesion via content-based language activities as more stimulating.

[5] Developing micro-skills like self and peer reviewing to share ideas and correct common errors.

\section{Course design}

Course design is a process that interprets the data gathered by NA (Hutchinson \& Waters 2009) to 'be transformed into a series of lessons to facilitate subsequent process of syllabus design, materials selection and classroom teaching and evaluation" (Yalden 1987: 10). Formulating goals and objectives is a key aspect of designing an EAP course: Goals (or aims) refer to the overall, longterm purposes of the course, whereas objectives 'describe the specific ways in which the goals will be achieved' (Richards, 2001: 17).

\subsection{Course goals}

Based on the issues identified in the introduction and the priorities gleaned from NA and DT in Part 2, this course is designed to help students:

[1] Develop the confidence and skills needed for writing a well-structured, relevant and coherent essay for academic purposes.

[2] Upgrade the quality of their writing and raise awareness to conventions of academic discourse.

[3] Develop their analytical and critical thinking skills ( a key issue discussed earlier in 1.3.4) through class discussions, readings and different activities.

[4] Develop personal and collaborative writing skills to prepare for workplace writing.

\subsection{Course objectives}

By the end of the program, the learners should be able to: 


\begin{tabular}{|c|c|c|c|}
\hline & $\begin{array}{l}\text { Related to } \\
\text { Weaknesses } \\
(2.5 .1) \\
\end{array}$ & $\begin{array}{l}\text { Priorities } \\
(2.6)\end{array}$ & $\begin{array}{l}\text { Goals } \\
(3.1)\end{array}$ \\
\hline $\begin{array}{l}\text { 1) Address a particular rhetorical mode/essay type; } \\
\text { namely, argumentation, and formulate a good } \\
\text { thesis, supported with examples, quotations, etc. }\end{array}$ & 1 & 1 & 1 \\
\hline $\begin{array}{l}\text { 2) Transfer and utilize the content, vocabulary and } \\
\text { organization of 'input' texts as a springboard } \\
\text { for their own writing. }\end{array}$ & $2,3,4$ & $2,3,4$ & 2 \\
\hline $\begin{array}{l}\text { 3) Develop logical reasoning to analyze and evaluate } \\
\text { information in order to develop or refute an argument. }\end{array}$ & 1 & 1 & 3 \\
\hline 4) Develop their range of academic lexis. & 2 & 2 & 1,2 \\
\hline $\begin{array}{l}\text { 5) Develop writing grammatical and lexical cohesion } \\
\text { through contextualized language exercises (as better than } \\
\text { discrete grammar activities as discussed in 1.3.1), } \\
\text { focusing on writing-related problems. }\end{array}$ & 3,4 & 3,4 & 1,2 \\
\hline $\begin{array}{l}\text { 6) Practice and develop the Micro-skills of planning, } \\
\text { drafting and editing their own and their peers' writings, to } \\
\text { produce an error-free, polished piece of writing. }\end{array}$ & 5 & 5 & $1,2,4$ \\
\hline
\end{tabular}

\subsection{Syllabus Type}

A syllabus can be simply described as a pedagogic statement of the course contents (Breen 2005); 'a list of knowledge and skills within the framework of overall aims, content appropriate to needs and culture and basis for evaluation' (Widdowson, 1987: 65). As discussed earlier in 1.3.3, an EGAP skills syllabus can meet the identified institutional and learning needs. It focuses on developing a set of generalized academic writing sub-skills and cognitive strategies brainstorming, planning, drafting, etc., learners can transfer to their specific disciplines at a later stage (Richards, 2001) to cope with different academic demands.

\subsection{The teaching strategy /Approach}

The eclectic teaching approach is adopted to synthesize process, product and genre approaches to writing:

- A genre approach is helpful in using real texts to contextualize the writing tasks and develop familiarity with features (linguistic, socio-cultural, etc.) of the written discourse (Tribble, 1996; Swales, 1990) . It is implemented at intial stages (see A 6.1) to sensitize learners tothe main conventions of the genre taught like target, cohesion, readers'perspective (McCarthy ,1991), etc.

- The product approach- though less creative as learners imitate a model text- can promote their accuracy and general comprehension of appropriate academic writing register, content and form (Jordan 1999; Hedge 2005) (see A 6.2, A 6.3) to boost their confidence as a prelude to writing on their own.

- The process approach effectively teaches strategies for planning, revising and editing ( see course outline ) and develop sense of audience (Hedge 2000; White \& Arndit 1999). Though 
time-consuming (Raimes ,1983 ), it leaves room for students to learn from their mistakes (White \& Arndit 1999) and gradually overcome their shortcomings identified in the DT results ( 2.5.1).

\subsection{Course content}

\subsubsection{Tasks Type}

- This course consists of 2-hour lessons, to be held every Tuesday for the 12 weeks of the second academic semester. It covers one main module, assigned by the college curriculum; namely, argumentative discourse. The tasks are 'building from more concrete (or controlled) to more open-ended '(Richards, 2001) and cyclical to cover the three key stages of prewriting, writing and re-writing.

- Throughout, interaction patterns vary from pairs to groups and whole class discussions. Opportunities for group compositions, self-assessment ,peer editing- using checklists (see A 7.1.2/ A 7.1.3) -and conferencing with the tutor are also offered to refine writing and 'build rapport and confidence' (Hedge, 2000:132). There is a lot of repetition and recycling - 'spiralling' (Graves, 2000) - along with regular homework (see course plan) to consolidate and provide repeated practice.

\subsubsection{Lessons Sequence}

- Lessons adopt a linear sequence based on a series of graded, skills- building tasks: learners usually start with a holistic approach to the target discourse treatment. They deductively identify the genre key features, related lexis and structures in an input reading text (see A 6.1, A 6.2, A 6.3). Accuracy-based activities cumulatively lead to guided construction of logically organized, cohesive essays, using the features highlighted. Freer writing activities are then implemented to enhance learners' writing proficiency and centeredness (Jordan, 2009).

- The class Wiki is utilized to overcome shortcomings of space and time (as discussed earlier in 1.3.5), enhance learners' collaboration and leave room for freer writing practice (see course outline).

\subsubsection{Materials}

- 'Effective Academic Writing 3' is the main resource used as deemed a 'student-centered' textbook in its content and sequence which are consistent with learners' identified needs, syllabus demand and exam requirements:

- The topics discussed- e.g. 'plagiarism', 'free cable'- are appropriate to students' social and cultural context.

- The target module provides good coverage of rhetorical functions, grammatical structures and vocabulary related to argumentative discourse. (see appended materials).

- Most activities foster critical thinking and provide a context for writing assignments.

- Tasks also balance accuracy and fluency, process and product approaches.

- Online self-access materials (see A6.3/A 6.6) encourage learner autonomy, supplement the class sessions and provide a venue for further writing practice.

- Some rubrics and editing checklists (A 7.1.1, A 7.1.2, A 7.1.3) are adapted from online sources or university data as more in tune with learners' pedagogical as well as real-life needs and promote their critical ability to assess theirs and others' writings (Dubin \&Olshtain, 2000). 


\subsection{Constraints}

\subsubsection{Institutional and cultural constraints}

- The choice of topics is generally determined by cultural sensitivity (as discussed earlier in 1.3.2) as not to be offensive or at odds with Saudi cultural norms. The tutor, for cultural reasons, discarded the discussion of controversial issues like 'Female driving'; it is prohibited in KSA.

\section{Assessment and Course Evaluation}

\section{1 $\underline{\text { Assessment }}$}

Assessment refers to a set of processes by which we' determine and pass judgments on students' learning potential and performance' (Hedge, 2005: 351). It is a multi-faceted concept relevant to teaching, learners' needs, and course evaluation (Baxter 1999). Such concepts of validity, reliability and practicality are crucial for conducting effective assessment procedures (Brown, 2010). Teacher assessment of learners can be both formative and summative.

\subsubsection{Formative Assessment}

Formative assessment is usually an in-class, on-going process, conducted by the teacher to' provide information about learners' progress -with relevance to their identified needs and course objectives' (Graves, 2000:208). Though less formal, it is 'pedagogically motivating' (Nunan, 1996:88) since it provides basis for further classroom work. (Brown, 2010).

In terms of assessment on this course, as my objectives (see 3.2) are mainly skills focused, I plan to use the following range of formative assessment methods:

\subsubsection{Feedback Forms}

- Periodic feedback forms act as an information-gathering tool that provides formative and ongoing assessment (Hughes, 2000) of learners' performance during the course. I will use them occasionally (see A 7.1.1) to enable students to monitor their progress (Hedge, 2005) and set goals for themselves.

\subsubsection{Self and Peer Assessment Forms}

- I will also attempt to enhance learners' ability to do self and peer assessment. I will supply them with a self -rating form (see A 7.1.2) to grade their own performance. Meanwhile, they will use checklists with marking criteria to assess their peers' work (see A 7.1.3). Self and collaborative assessment (Objective 6/ section 3.2) can help to locate their and others 'strengths and weaknesses and take decisions in their language learning development (Harris\& McCann, 1994; Nunan 1996). Their forms will be ultimately compared to the ones filled by the teacher, following a training session on assessing a sample text, in order to reduce stress and guarantee both reliability and validity of their assessment.

\subsubsection{Progress Tests}

- I will have two main writing progress tasks. Both aim to assess learners' performance, 95 
demonstrate their achievement and monitor their progress as well (Baxter 1999; Hedge, 2000). The tasks are taken from past university exam papers to familiarize them with exam tasks. Moreover, the two tasks have both high face and construct validity (Brown, 2010) because they measure what students know and expect and simulate the final exam. They are to be marked using university analytical scale (see A 7.1.4) and then double-marked by one of my colleagues to reduce subjectivity and guarantee reliability of marking (Jordan, 2009). As stated earlier in the NA results (see 2.4) and course objectives (see 3.2), the course aims to promote the overall written performance of learners, not only their linguistic competencies. Therefore, no discrete language items will be used, either in the activities nor in the assessment, to avoid negative backwash;

\subsubsection{Summative Assessment}

In contrast to formative assessment, summative assessment is usually carried out formally, often at the end of a course, in the form of proficiency or achievement tests to establish grades and measure learners' level as well as the overall effectiveness of the course (Brown, 2010). It, hence, provides general feedback on learning outcomes to plan better future courses (Hughes, 2005).

In terms of summative assessment at the end of the course, I have the following plan:

\subsubsection{Achievement Test}

I will administer an achievement test in the form of a written assignment - a 1000 word argumentative essay. It aims to assess learners ' ability to develop or refute a thesis (objectives 1,3 ) and practice skills like planning, drafting and editing (objective 6) to produce an acceptable piece of writing, in both form and content (objectives 4, 5). In order to make the assessment as objective as possible, the essay is to be criterion-referenced; it will be judged against university's analytic marking scheme (see A 7.2) to give data concerning the competencies learners have acquired during the course. Negative backwash is, accordingly, also reduced here as the task examines what students have practiced (Brown 2010) and covers the course content- a situation that guarantees both content and face validity (Jordan 2009; Hedge 2000). Second marking will be also done for the sake of the reliability of the results.

\subsection{Course Evaluation}

Evaluation is a wider term that acts on 'the empirical data of assessment results to indicate the worth or merit of a program' and 'inform decision making' (Jordan, 2009: 85) for future courses. It is essential to gauge the course delivery in relation to learners' needs and prescribed objectives (Hutchinson \&Waters 1987; Nunan 1996). This may lead to modify or alter course aims or content for more effective future delivery.

A range of methods will be used to evaluate my course:

\subsubsection{Quantitative Evaluation}

\subsubsection{Test Results}

- Quantitative evaluation will be based on the analysis of the summative assessment; namely, test results, as indicative of students' progress and ability to perform the target academic tasks (Hyland, 2006).

\subsubsection{Qualitative evaluation}

\subsubsection{Student Survey Questionnaire}


- Learners' evaluation of the course aids to check its effectiveness in meeting objectives and provide insight by involving 'all concerned parties' to 'assess how well the needs that have created the demand for a course are being served' (Hutchinson \& Waters, 2009: 156). The final summative student survey questionnaire (see A 5.1) will, therefore, be administered anonymously in class, in the absence of the teacher, to leave room for honest reflections on the course (Hedge, 2000).

\subsubsection{Informal Interview}

- I intend then to hold an informal, post-course interview (Hedge, 2005) with the learners to elicit their feedback and gain an understanding of their perception of its usefulness for their short and long-term needs and goals.

\subsubsection{Teacher Self-Report}

- The teacher self-report (see A 5.7)- another type of formative evaluation- will aim to review course content, objectives and teaching methodology (Ibid.) and suggest modifications for future courses.

\section{Conclusion}

\subsection{Benefits for learners}

- In section 1, I outlined a number of key issues, relevant to designing EAP courses. My proposed course aims to enable learners to practice academic writing, particularly argumentation. It is principally an EGAP course to provide them with generic, transferable skills they can later adapt to their chosen specialisms. It also raises their awareness of the main features of written discourse that will benefit them in their future academic or vocational life.

- The course aims and objectives are determined by the detailed needs analysis and the findings of the diagnostic test to address their needs. The skills-focused syllabus, along with the eclectic teaching approach, provides ample room for analytical thinking, writing practice, self-study and collaborative work. The input provided aids to promote their autonomy and develop their critical consciousness (Chazel , 2012) to ultimately become more responsible for their learning in the future.

- At the end of the course, they will potentially become more successful writers. Compared to the DT results, their final test marks should be higher due to visible improvement in cohesion, ideas development, and lexical and syntactic accuracy.

\subsection{Course Limitations}

This course covers the duration of only 24 hours. It focuses on one writing module; namely, argumentative discourse. Other essay types are not addressed for not being assigned by college at this level, though needed by learners in their specific disciplines: IT learners, for example, need to experiment with genres they may need later like process analysis.

Moreover, some objectives like expanding the range of academic vocabulary (objective 4) are not properly handled due to the time constraints. In the post-course informal interview, I will provide learners with a list of specialized websites for more practice to build on their current knowledge. I will also try, in future courses, to experiment with more online tools and activities to further their practice outside the classroom. 
All in all, I think the course can be quite successful and achieve most of its objectives. I feel more eager now to design more EAP courses in the near future.

\section{References:}

[1] Baxter, Andy (1999). Evaluating Your Students: Handbooks for Teachers, Richmond.

[2] P. Breen, (2005), ' Beliefs about Language Learning', TESL-EJ, 9, 1.

[3] H. Brown, Douglas (2010). Language Assessment: Principles and Classroom Practices, Pearson.

[4] Bynom, Anthony(2001). 'Testing Terms', English Teaching Professional, 20, p.8

[5] Cox, Kathy \& Hill, David (2011). EAP Now, 2nd edition. Pearson.

[6] De Chazal, Edward (2013). Teaching and Learning EAP, Retrieved 22 March 2014, from: http://oupeltglobalblog.com

[7] Dubin, Fraida \& Olshtain, Elite (2000), Course Design, Cambridge UP.

[8] Dudley-Evans, Tony\& St John, Maggie (1998). Developments in English for Specific Purposes: A Multi-Disciplinary Approach, OUP.

[9] Evans, Stephen \& Morrison, Bruce (2011). The First Term at University: Implications for EAP. ELT Journal 56: 4, 387-397.

[10] Gillett, Andy (1996). What is EAP? IATEFL ESP SIG Newsletter, 6, 17-23.

[11] Graves, Kathleen. (2000). Teachers as Course Developers, Cambridge UP.

[12] Guse, Jenni (2011). Communicative activities for EAP. Cambridge: CUP.

[13] Hamp-Lyons, Liz \& Heasley, Ben (2006), Study Writing, Cambridge UP.

[14] M. Harris, and P. McCann (1994). Assessment. Oxford: Heinemann.

[15] Hedge, Tricia. (2005), Writing, Oxford UP.

[16] Hedge, Tricia. (2000), Teaching and Learning in the Language Classroom, Oxford UP.

[17] Hutchinson, Tom \& Waters, Alan (2009), English for ESP, Cambridge UP.

[18] Hughes, Arthur (2003). Testing for Language Teachers, Cambridge UP.

[19] K. Hyland (2002) 'Specificity revisited: how far should we go now?' English for Specific Purposes, 21, 385-95.

[20] K. Hyland, and Hamp-Lyons, Liz (2002). EAP: Issues and Directions. Journal of English for Academic Purposes 1, 1-12

[21] K. Hyland, (2006). English for Academic Purposes, Routledge.

[22] R.R. Jordan, (2009). English for Academic Purposes, 11th edition. Cambridge UP.

[23] R.R. Jordan, (1999). Academic Writing Course: Study Skills in English, Longman.

[24] Long, Michael H (2005). Second language Needs Analysis, Cambridge UP. 
[25] R. Mackay, and A. Mountford, (1978). English for Specific Purposes, Longman Publishing Group.

[26] M. McCarthy, (1991). Discourse Analysis for Language Teachers. Cambridge: Cambridge University Press

[27] Nunan , David (1996). The learner-centered curriculum, Cambridge UP.

[28] A. Raimes, (1983). Techniques in Teaching Writing. Oxford University Press

[29] Richards, Jack C (2001). Curriculum Development in Language Teaching, Cambridge UP.

[30] Rogers, Louis(2010) . 'An all-round challenge 1', English Teaching Professional, 69.

[31] Spack, Ruth (1988) 'Initiating ESL students into the academic discourse community: how far should we go?’ TESOL Quarterly, 22 (1), 29-52.

[32] J. Swales, (1990). Genre Analysis. Cambridge UP.

[33] Thorp, Dilys (1991). Confused encounters: differing expectations in the EAP classroom. ELT Journal 45:2,108-118.

[34] C. Tribble, (1997). Writing, Oxford UP.

[35] J. Turner, (2004). Language as Academic Purpose. Journal of English for Academic Purposes 3:2, 95-109.

[36] R. White and Arndt, V. Ron (1991), Process Writing, Longman.

[37] H.G. Widdowson, (1987). Aspects of syllabus design. In Tickoo (Eds.), Syllabus design: The state of art. Singapore: Regional English Language Centre.

[38] H.G. Widdowson, (1978) Teaching Language as Communication, OUP.

[39] Williams, Marion (1999). 'Motivation in language learning', English Teaching Professional, 13.

[40] Yalden, Janice. (1987). Principles of Course Design for Language Teaching. Cambridge UP.

\section{Course Books and Materials:}

[1] Cottrell, Stella (2008). The Study Skills Handbook, $3^{\text {rd }}$ edition, Macmillan)

[2] Liss, Rhonda \& Davis, Jason. (2013) 'Effective Academic Writing 3', 2nd ED. Oxford UP.

[3] Longman, John (2011). College writing skills with readings, $8^{\text {th }}$ Ed. McGraw hill International, 381.

[4] Official Ielts Practice Material (2007), Cambridge UP.

[5] Wingate, Jim. (1996). 'Multiple Intelligences', ETP, 1 October, pp.28-31

\section{Web Materials used:}

[1] http://www.ielts.org/researchers/score_processing_and_reporting.aspx

[2] http://www.teachingenglish.org.uk/article/planning-a-writing-lesson-

[3] http://www.ltn.lv/ markir/essaywriting/frntpage.html

[4] https://elt.oup.com/teachers/eaw/ 


\section{Appendix 1 \\ Course Proposal}

\section{Appendices}

\section{Course details}

This course consists of 2-hour lessons, to be held every Tuesday for the 12 weeks of the second academic semester, with a total of $24 \mathrm{hrs}$.

\section{Course Overview:}

This course covers one main module; namely, argumentative discourse. It is mainly a skills- based course, based on a number of skill- building tasks like brainstorming, generating ideas, planning and drafting. The tasks are varied and graded to ultimately enhance learners' overall writing proficiency.

\section{$\underline{\text { Lesson Structure }}$}

Most lessons start with awareness- raising activities followed by discussing and analyzing an input text or a sample essay to highlight subject-specific grammar, structures and lexis. Controlled practice activities are ensued by freer practice to enable learners to write independently. Peer or group review follows self-evaluation while teacher evaluation comes at the end to steer learners on track.

\section{Course objectives}

By the end of the program, the learners should be able to:

[1] Address a particular rhetorical mode/essay type; namely, argumentation, to formulate a good thesis, supported with examples, quotations, etc.

[2] Transfer and utilize the content, vocabulary and organization of sample essays and 'input' reading texts as a springboard for their own writing.

[3] Develop logical reasoning to analyze and evaluate information in order to develop or refute an argument.

[4] Develop learners' range of academic lexis.

[5] Develop writing grammatical and lexical cohesion through contextualized language exercises, focusing on writing-related problems.

[6] Practice and develop the Micro-skills of planning, drafting and editing their own and their peers' writings, to produce an error-free, polished piece of writing. 


\section{Week 1}

Time 2 hrs.

\begin{tabular}{|c|c|c|}
\hline $\begin{array}{l}\text { Learning outcomes / } \\
\text { Aims }\end{array}$ & Procedure & $\begin{array}{l}\text { Link to } \\
\text { objectiv } \\
\text { es }\end{array}$ \\
\hline $\begin{array}{l}\text {-- To raise awareness/ activate } \\
\text { schemata about academic writing } \\
\text { requirements. } \\
\text { - To develop critical thinking by } \\
\text { analyzing } \\
\text { and discussing the model text. } \\
\text { - To notice the language of argume } \\
\text { used in the text, and familiarize lear } \\
\text { with the structure and rhetorical } \\
\text { features of the genre. } \\
\text {-To brainstorm specific } \\
\text { vocabulary related to the } \\
\text { language of argument to use later } \\
\text { in their writings. } \\
\text { - To develop pre-writing skills; } \\
\text { mainly, brainstorming and free } \\
\text { writing. }\end{array}$ & $\begin{array}{l}\text { - Introducing course content, objectives and orientation with } \\
\text { class Wiki. } \\
\text { - Quiz about features of academic writing (register, processes, etc.) } \\
\text { - Brainstorm ideas about the topic of } \\
\text { of 'free cable' in pairs and then in an open class discussion to list points for and } \\
\text { against. } \\
\text { - Learners scan the text to fill in the form (A 6.1) about voice, Itarget } \\
\text { audience and organization, circle controlling ideas, underline } \\
\text { cohesive devices /signal words expressive of the language of } \\
\text { argument and techniques of support. } \\
\text { - In pairs, they categorize them } \\
\text { into positive, neutral and negative and try to come up with more relevant } \\
\text { collocations and expressions. } \\
\text { HW: free writing about a current debate and share ideas on the Wiki forum } \\
\text { to discuss next cl }\end{array}$ & $\begin{array}{l}\text { (1), (2) } \\
\text { (4), (5) }\end{array}$ \\
\hline
\end{tabular}

\section{Materials: 'Effective Academic Writing 3'}

Genre analysis form (sample A 6.1)

\section{Week 2}

Time 2 hrs.

\begin{tabular}{|c|c|c|}
\hline Learning outcomes & Procedure & Link to objectives \\
\hline $\begin{array}{l}\text {-To develop a deeper } \\
\text { understanding of the macro, } \\
\text { organizational features of } \\
\text { argumentative discourse. } \\
\text { - To develop learners' lexical } \\
\text { repertoire and develop } \\
\text { further awareness of register. }\end{array}$ & $\begin{array}{l}\text { - Re-cycle the concepts taught last class and } \\
\text { discuss students' posts on class Wiki. } \\
\text { - Further discussion of argumentation } \\
\text { organization and different ways to support a } \\
\text { cause to add to the board map. } \\
\text { - Controlled practice: Handle an activity } \\
\text { about identifying collocations with } \\
\text { argumentative vocabulary in the course } \\
\text { book and filling in the table with elicited } \\
\text { words and expressions. } \\
\text { - A freer practice: In groups, students create } \\
\text { half stem sentences for each other to } \\
\text { complete, using the expressions taught. } \\
\text { HW: on class Wiki, learners create two } \\
\text { groups to share ideas for and against the } \\
\text { topic discussed. }\end{array}$ & $\begin{array}{r}\text { (1), (3) } \\
\text { (4) }\end{array}$ \\
\hline
\end{tabular}

\section{Materials: 'Effective Academic Writing 3'(sample A 6.2) \\ Week 3}

Time: 2 hrs. 


\begin{tabular}{|c|c|c|}
\hline Learning outcomes & Procedure & Link to objectives \\
\hline $\begin{array}{l}\text { - To elicit strategies to } \\
\text { expand an argument. } \\
\text { - To develop logical } \\
\text { reasoning to judge different } \\
\text { types of evidence. }\end{array}$ & $\begin{array}{l}\text { - A quick re-cap and comments on } \\
\text { Wiki posts. } \\
\text { - Class discussion of techniques of } \\
\text { providing support like factual } \\
\text { details, anecdotes, statistics, } \\
\text { analogies and citing authorities. } \\
\text { - Scan the model text to list types } \\
\text { of evidence provided in pairs. } \\
\text { Open discussion to elicit more. } \\
\text { - Judge different propositions to } \\
\text { fallacies and valid arguments and } \\
\text { rank reasons in terms of } \\
\text { importance or value to determine } \\
\text { ones need evidence. } \\
\text { - Tutor gives F/B to } \\
\text { establish the correct } \\
\text { answers. } \\
\text { - In pairs, learners formulate a } \\
\text { proposition about the topic, } \\
\text { supported with concrete evidence. } \\
\text { - They swap to judge, teacher } \\
\text { monitors and provides final } \\
\text { comments. } \\
\text { HW: } \\
\text { Handle online exercises from 'the } \\
\text { additional resources' for further } \\
\text { practice. }\end{array}$ & (1), (3) \\
\hline
\end{tabular}

Materials: 'Effective Academic Writing 3'(sample A 6.3)

\section{Week 4}

Time: 2 hrs.

\begin{tabular}{|l|l|l|}
\hline Learning outcomes & Procedure & Link to objectives \\
\hline $\begin{array}{l}\text { - To re-cycle academic } \\
\text { referencing conventions, } \\
\text { paraphrase and summary. }\end{array}$ & $\begin{array}{l}\text { - Open discussion to check comprehension } \\
\text { of keys terms of citation, summary and } \\
\text { paraphrase. }\end{array}$ & \\
$\begin{array}{l}\text { - To provide further } \\
\text { practice of these tools as } \\
\text { means to buttress a claim } \\
\text { or thesis. }\end{array}$ & $\begin{array}{l}\text { - Learners, in pairs, paraphrase parts of } \\
\text { the original text about 'plagiarism'. }\end{array}$ & \\
& $\begin{array}{l}\text { - They, then, compare original text with its } \\
\text { sumary, to gauge it, using a rubric }\end{array}$ & (1), (3) \\
& $\begin{array}{l}\text { - They summarize parts of it and swap to } \\
\text { get the F/B. }\end{array}$ & \\
& HW: They are encouraged to share ideas & \\
& $\begin{array}{l}\text { on class Wiki about the model text to } \\
\text { make it stronger to compose their first } \\
\text { draft. }\end{array}$ & \\
\hline
\end{tabular}

\section{Materials: 'Effective Academic Writing 3'(sample A 6.4)}

\section{Week 5}

Time: $2 \mathrm{hrs}$. 


\begin{tabular}{|c|c|c|}
\hline Learning outcomes & Procedure & Link to objectives \\
\hline $\begin{array}{l}\text { - To develop proof- } \\
\text { reading skills and } \\
\text { enhance learner } \\
\text { autonomy. } \\
\text { - To develop re-drafting, } \\
\text { self-reflective practices } \\
\text { and the ability to self- } \\
\text { correct. } \\
\text { - To raise awareness to } \\
\text { one's learning outcomes, } \\
\text { strengths and } \\
\text { weaknesses, using } \\
\text { assessment criteria. }\end{array}$ & $\begin{array}{l}\text { - In small groups, learners share } \\
\text { one draft. } \\
\text {-Teacher models assessing a } \\
\text { sample essay, using university } \\
\text { grading rubric. } \\
\text { - Learners re-check their drafts, } \\
\text { using the self-grading form. } \\
\text { - Peer editing of drafts, using the } \\
\text { marking grid. } \\
\text { - Open discussion of common } \\
\text { problems. } \\
\text { Formative Assessment Task: } \\
\text {-Students are to upload the final } \\
\text { draft on class Wiki. } \\
\text { - Teacher provides comments and } \\
\text { gives marks. } \\
\text { - Post reflections freely on class } \\
\text { Wiki to compare assessments and } \\
\text { track progress. }\end{array}$ & $(5),(6)$ \\
\hline
\end{tabular}

Materials: Self-grading from (sample A 7.1.2)

Peer assessment form (sample A 7.1.3)

Sample progress tests (A 7.1.5)

\section{Week 6}

Time: 2 hrs.

\begin{tabular}{|c|c|c|}
\hline Learning outcomes & Procedure & Link to objectives \\
\hline $\begin{array}{l}\text { - To check learners' view } \\
\text { of the course and adjust } \\
\text { plans, if } \\
\text { needed. } \\
\text { - Raise awareness to core } \\
\text { concepts of counter-argum } \\
\text { concessions, } \\
\text { refutation and } \\
\text { hedging. } \\
\text { - To familiarize learners wi } \\
\text { forms and structures releva } \\
\text { to concessions and refutati } \\
\text { - To develop grammatical } \\
\text { lexical cohesion. }\end{array}$ & $\begin{array}{l}\text { - Students fill in a F/B form } \\
\text { about the course so far. } \\
\text {-Open discussion of these } \\
\text { terms. } \\
\text { - Identify refutations and concessions. } \\
\text { - Notice forms and expressions used. } \\
\text { - Do a grammar review of linkers of } \\
\text { addition/contrast, expressing certainty, } \\
\text { quantity, and frequency to qualify a } \\
\text { thesis. } \\
\text { HW: } \\
\text {-More practice on wiki of connectives } \\
\text { of concession. } \\
\text {-Learners should also prepare a list of } \\
\text { topics to vote for the next assignment. }\end{array}$ & (1), (2), (3) \\
\hline
\end{tabular}


Materials: 'Effective Academic Writing 3' (sample A 6.5/ A 6.6)

\section{Week 7}

Time: 2 hrs.

\begin{tabular}{|l|l|l|}
\hline Learning outcomes & Procedure & Link to objectives \\
\hline $\begin{array}{l}\text { - To build an effective } \\
\text { proposition. } \\
- \text { To anticipate opposition to } \\
\text { refute or concede. } \\
\begin{array}{l}\text { - To brainstorm and generate } \\
\text { ideas }\end{array}\end{array}$ & $\begin{array}{l}\text { - Open discussion of the topics list to settle on } \\
\text { one. }\end{array}$ & $\begin{array}{l}\text { - Free writing to brainstorm ideas. } \\
\text {-Divide class into supporters and opponents/ } \\
\text { engage them in in a pyramid discussion to shar } \\
\text { ideas. } \\
\text { - Create a final pro and con chart. } \\
\text { HW: }\end{array}$ \\
$\begin{array}{l}\text { Both supporters and opponents exchange more } \\
\text { ideas on class Wiki. }\end{array}$ & & (6) \\
& & \\
\end{tabular}

\section{Week 8}

Time: 2 hrs.

\section{Week 9}

\begin{tabular}{|l|l|l|}
\hline Learning outcomes & Procedure & Link to objectives \\
\hline - To practice planning. & $\begin{array}{l}\text { - Re-cycle the concepts previously taught. } \\
\text { - Learners, in pairs, outline their argument. } \\
\text { - They write their first draft in class. }\end{array}$ & \\
- To practice drafting / & - Teacher monitors to provide some guidance \\
collaborative writing. & & \\
& & \\
& & \\
\end{tabular}

Time: 2 hrs. 


\begin{tabular}{|c|c|c|}
\hline Learning outcomes & Procedure & Link to objectives \\
\hline $\begin{array}{l}\text { - To raise awareness to } \\
\text { one's learning } \\
\text { outcomes, strengths and } \\
\text { weaknesses. } \\
\text {-To develop proof- } \\
\text { reading skills and } \\
\text { enhance learner } \\
\text { autonomy. }\end{array}$ & $\begin{array}{l}\text { - Teacher reformulates a sample essay } \\
\text { for learners to compare and correct their } \\
\text { drafts. } \\
\text { - Learners modify their drafts and add } \\
\text { comments. } \\
\text { - Teacher monitors to provide suggestions } \\
\text { give F/B. } \\
\text { - Students re-draft in small groups. } \\
\text { HW: learners upload final draft } \\
\text { on class Wiki for other groups to assess. }\end{array}$ & $(\mathbf{1}),(\mathbf{6})$ \\
\hline
\end{tabular}

\section{Week 10}

Time: 2 hrs.

\begin{tabular}{|c|c|c|}
\hline Learning outcomes & Procedure & Link to objectives \\
\hline $\begin{array}{l}\text { - To engage SS actively it } \\
\text { learning process. } \\
\text { - Raise awareness to self- } \\
\text { assessment and reflection }\end{array}$ & $\begin{array}{l}\text { - Open class discussions of common problem. } \\
\text { short list. } \\
\text { - Teacher assigns relevant review } \\
\text { tests for learners to handle individually.. } \\
\text { - They check in pairs, before getting the due } \\
\text { score. } \\
\text { - A post-discussion of their feedback. } \\
\text { - Class share ideas to finally produce error- } \\
\text { analysis/correction chart. } \\
\text { Second formative assessment task: } \\
\text {-Ss re-check draft for the last time, using writ } \\
\text { grading rubrics } \\
\text { rubrics . } \\
\text {-Teacher gives F/B and grades. }\end{array}$ & Overall objectives \\
\hline
\end{tabular}

\section{Materials: Rubrics for grading writing (Appendix 7.1.4)}

\section{'Effective Academic Writing 3' (review test sample A 6.7)}

\section{Sample progress tests (A 7.1.5)}

\section{Week 11}

Time: 2 hrs. 


\begin{tabular}{|c|c|c|}
\hline Learning outcomes & Procedure & Link to objectives \\
\hline $\begin{array}{l}\text { - To engage SS actively in } \\
\text { the learning process. } \\
\text {-To re-cap the whole course } \\
\text { - To check and track progress }\end{array}$ & $\begin{array}{l}\text { - Open class discussions of second assignment } \\
\text { F/B. } \\
\text { SS look at the objectives of the course and summar } \\
\text { what they think they have learnt . } \\
\text { - Teacher has individual tutorial for each student to } \\
\text { provide final advice for learners. }\end{array}$ & Overall objectives \\
\hline
\end{tabular}

\section{Week 12}

Time: 2 hrs.

\begin{tabular}{|l|l|l|}
\hline Learning outcomes & Procedure & Link to objectives \\
\hline $\begin{array}{l}\text { - To evaluate the } \\
\text { effectiveness of the course }\end{array}$ & $\begin{array}{l}\text { Students fill in a course evaluation } \\
\text { questionnaire. } \\
\text { - Oral discussion of their overall vision of the } \\
\text { course and suggestions for future ones. }\end{array}$ & Overall objectives \\
\hline
\end{tabular}

_Materials: Students' Survey questionnaire (Appendix 7.1.1)

\section{(Appendix 2)}

\section{(Appendix 2.1)}

\section{Needs analysis and diagnostic test collated results}

\section{Needs Analysis Collated Results}

\section{(Appendix 2.1.1)}

\section{Structured Interview}

The academic writing co-ordinator confirmed the following:

- Academic writing is a compulsory course.

- The textbook 'EFFECTIVE ACADEMIC WRITING 3 ' is chosen as it mixes process and product approaches plus language activities.

- Most learners have low language proficiency and cannot decide what to study.

- Their problems are mainly related to coherence, cohesion and grammatical accuracy.

- Their main goal is to pass the IELTS exam with a high score to get a governmental scholarship or study abroad. 


\section{(Appendix 2.1.2)}

\section{The questionnaire collated result}

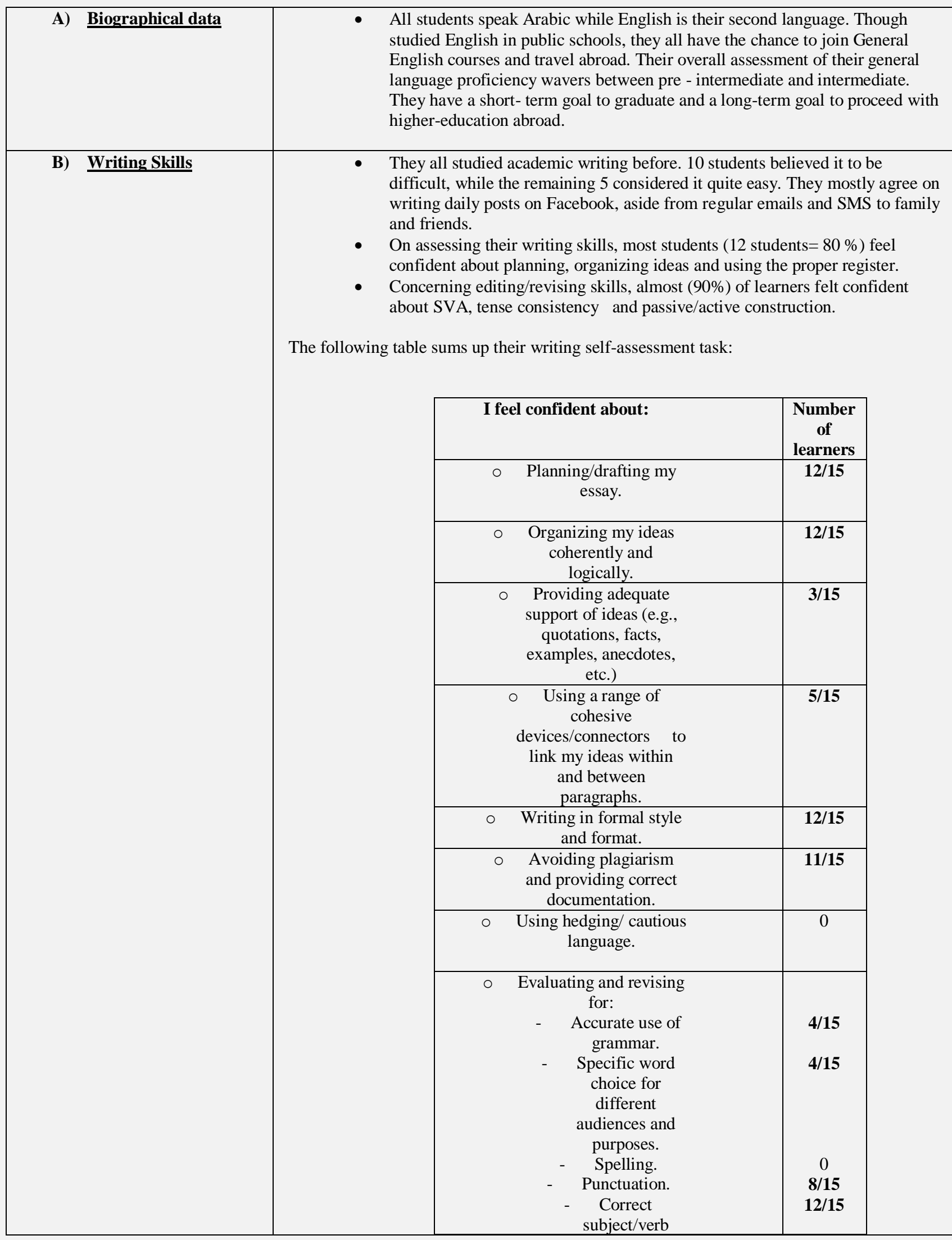




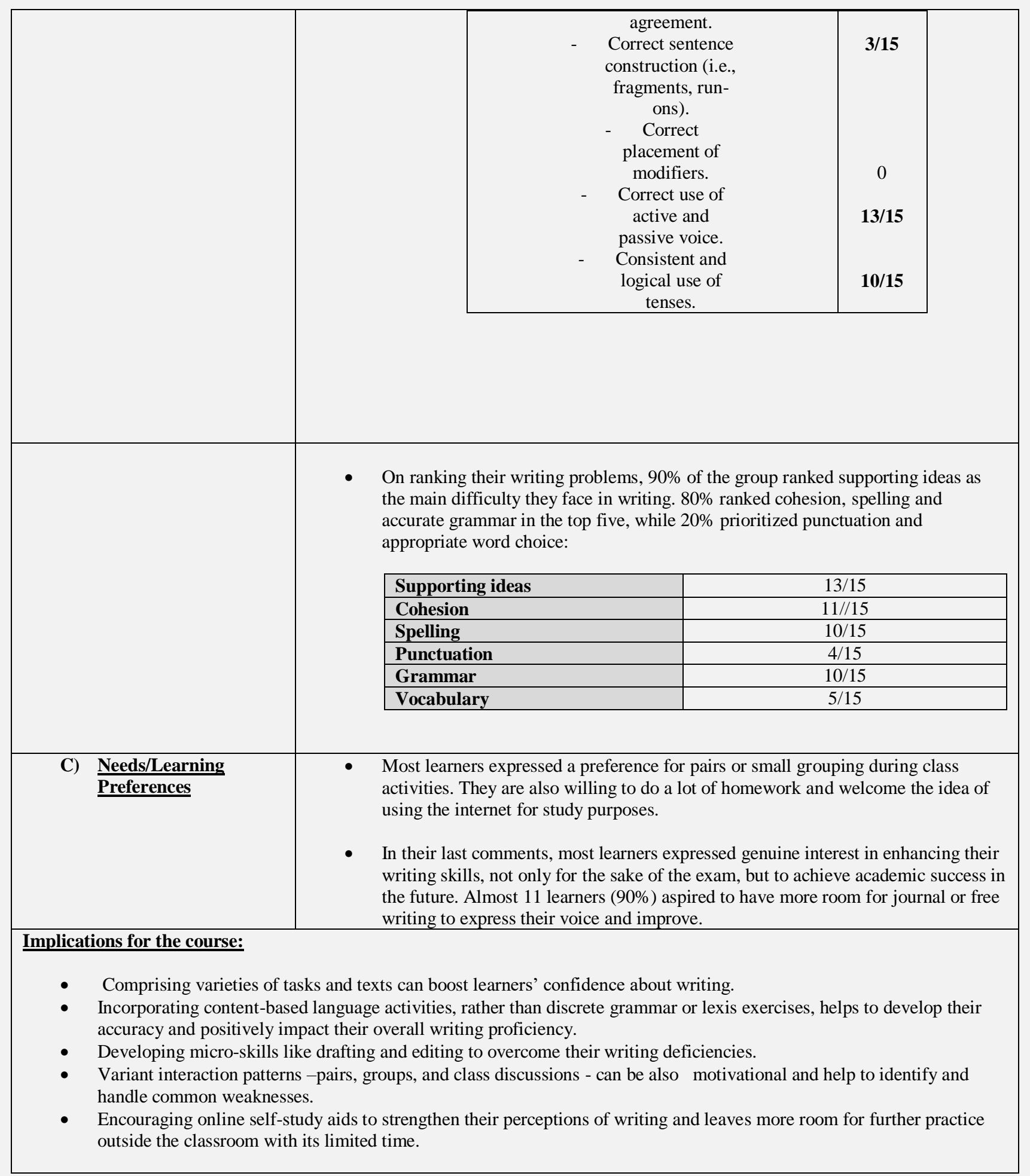

(Appendix 2.1.3)

Informal chats collated results 


\begin{tabular}{|c|c|}
\hline Writing instructors' problems & Learners' problems \\
\hline$\bullet \quad$ Most students lack motivation. & $\bullet \quad$ Tutors' feedback is insufficient. \\
\hline$\bullet \quad$ Grammar tasks are time-consuming. & $\bullet \quad$ Language tasks are over focused. \\
\hline$\bullet \quad$ Materials are sometimes dull. & $\bullet \quad \begin{array}{l}\text { Assessing their true writing competence is always } \\
\text { a problem. }\end{array}$ \\
\hline
\end{tabular}

\section{Appendix (2.2)}

\section{Diagnostic Test collated result Appendix (2.2.1) \\ Diagnostic Test results analysis Writing Task}

This table shows my assessment of my students' diagnostic writing task, including approximate band scores, based on the IELTS criteria at:

\section{(http://www.ielts.org/researchers/score processing and reporting.aspx).}

\begin{tabular}{|c|c|c|c|c|c|}
\hline $\begin{array}{l}\text { Number of } \\
\text { students }\end{array}$ & $\begin{array}{l}\text { Average } \\
\text { band }\end{array}$ & $\begin{array}{l}\text { Task } \\
\text { Achievement }\end{array}$ & $\begin{array}{l}\text { Coherence and } \\
\text { Cohesion }\end{array}$ & Lexical Resource & $\begin{array}{c}\text { Grammatical range and } \\
\text { Accuracy }\end{array}$ \\
\hline 3 & Band (6) & $\begin{array}{l}\text { - Addressed all parts } \\
\text { of the argumentative } \\
\text { essay although some } \\
\text { parts may need more } \\
\text { development. } \\
\text { - Presented a relevant } \\
\text { position. } \\
\text { - Presented relevant } \\
\text { main ideas but some } \\
\text { may be inadequately } \\
\text { developed/unclear. }\end{array}$ & $\begin{array}{l}\text { - Arranged information } \\
\text { and ideas coherently. } \\
\text { - Used cohesive devices } \\
\text { effectively, but cohesion } \\
\text { within and/or between } \\
\text { sentences may be faulty } \\
\text { or mechanical. } \\
\text { - Used paragraphing } \\
\text { properly. }\end{array}$ & $\begin{array}{l}\text { - Used a relatively } \\
\text { adequate range of } \\
\text { vocabulary for the task. } \\
\text { - Made some errors in } \\
\text { spelling and/or word } \\
\text { formation, but they do not } \\
\text { impede communication. }\end{array}$ & $\begin{array}{l}\text { - Used a mix of simple and } \\
\text { complex sentence forms. } \\
\text { - Made some errors in grammar } \\
\text { and punctuation but they rarely } \\
\text { reduce communication. }\end{array}$ \\
\hline 8 & Band (5) & $\begin{array}{l}\text { - Addressed the task } \\
\text { only partially.as } \\
\text { expressed a position } \\
\text { but the development } \\
\text { is not always clear } \\
\text { and there may be no } \\
\text { conclusions drawn. } \\
\text { - Presented some } \\
\text { main ideas but these } \\
\text { are limited and not } \\
\text { sufficiently } \\
\text { developed; there may } \\
\text { be irrelevant detail } \\
\text { (e.g. discussing } \\
\text { newspapers/housewi } \\
\text { ves' chores) }\end{array}$ & $\begin{array}{l}\text { - Presented information } \\
\text { with some organization } \\
\text { but there may be a lack of } \\
\text { overall progression. } \\
\text { - Made inadequate, } \\
\text { inaccurate or over use of } \\
\text { cohesive devices } \\
\text { (especially conjunctions) }\end{array}$ & $\begin{array}{l}\text { - Used a limited range of } \\
\text { vocabulary, (Many words } \\
\text { are repeated), but this is } \\
\text { minimally adequate for the } \\
\text { task. } \\
\text { - May make noticeable } \\
\text { errors in spelling and/or } \\
\text { word formation } \\
\text { (technologists, programies, } \\
\text { etc.) that may cause some } \\
\text { difficulty for the reader. }\end{array}$ & $\begin{array}{l}\text { - Used only a limited range of } \\
\text { structures. } \\
\text { - Attempted complex sentences } \\
\text { but these tend to be less } \\
\text { accurate than simple sentences. } \\
\text { - May make frequent } \\
\text { grammatical errors ; } \\
\text { errors can cause some difficulty. } \\
\text { for the reader. } \\
\text { (there is many ways, } \\
\text { TV can make us to } \\
\text { enjoy, etc.) }\end{array}$ \\
\hline
\end{tabular}




\begin{tabular}{|c|c|c|c|c|c|}
\hline $\begin{array}{l}\text { Number of } \\
\text { students }\end{array}$ & $\begin{array}{l}\text { Average } \\
\text { band }\end{array}$ & $\begin{array}{l}\text { Task } \\
\text { Achievement }\end{array}$ & $\begin{array}{l}\text { Coherence and } \\
\text { Cohesion }\end{array}$ & Lexical Resource & $\begin{array}{c}\text { Grammatical range and } \\
\text { Accuracy }\end{array}$ \\
\hline 4 & Band (4-4.5) & $\begin{array}{l}\text { - Responded to the } \\
\text { task only in a } \\
\text { minimal way. } \\
\text { - Presented a position } \\
\text { but this is unclear. } \\
\text { - Presented some } \\
\text { main ideas but these } \\
\text { are difficult to } \\
\text { identify and may be } \\
\text { repetitive, irrelevant } \\
\text { or not well } \\
\text { supported. }\end{array}$ & $\begin{array}{l}\text { - Presented information } \\
\text { and ideas but these are } \\
\text { not arranged coherently } \\
\text { and there is no clear } \\
\text { progression in the } \\
\text { response. } \\
\text { - Used some basic } \\
\text { cohesive devices but } \\
\text { these may be inaccurate } \\
\text { or repetitive (and, and so, } \\
\text { etc.). } \\
\text { - May not write in } \\
\text { paragraphs or their use } \\
\text { may be confusing. }\end{array}$ & $\begin{array}{l}\text { - Used only basic } \\
\text { vocabulary which may be } \\
\text { used repetitively or which } \\
\text { may be inappropriate for } \\
\text { the task. } \\
\text { - Had a relatively limited } \\
\text { control of word formation } \\
\text { and/or spelling; errors may } \\
\text { cause strain for the reader. }\end{array}$ & $\begin{array}{l}\text { - Used only a limited range } \\
\text { of structures with rare } \\
\text { use of subordinate clauses. } \\
\text { - Some structures are accurate } \\
\text { but many errors were detected. } \\
\text { - Some problems of punctuation.. }\end{array}$ \\
\hline
\end{tabular}

\section{Appendix (2.2.2)}

A summary of learners' error frequency:

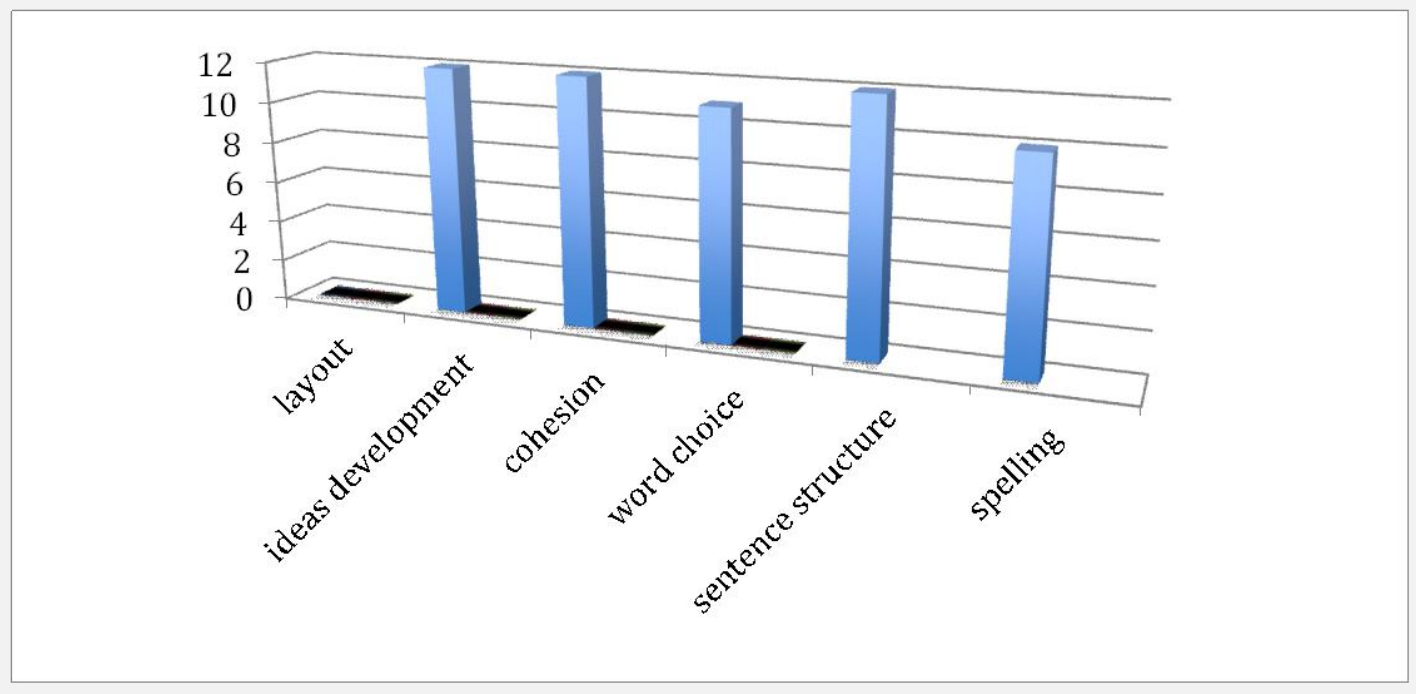

\begin{tabular}{|l|l|}
\hline 0 & Organization/layout \\
\hline 12 students & Ideas development \\
\hline 12 students & Cohesion \\
\hline 11 students & Word choice \\
\hline 12 students & Sentence structure \\
\hline 10 students & Spelling \\
\hline
\end{tabular}

